\title{
Evaluation of water resources carrying capacity based on cultivated land and urban construction scale -- a case study of Jinzhou City
}

\author{
GAO Mengmeng ${ }^{1}$, Li Xiaolei ${ }^{1, \text { a }}$,Yang Nan ${ }^{1}$, Sun Xiubo ${ }^{2}$, Liu Qiong ${ }^{1}$, Wang $\mathrm{Yi}^{1}$ \\ ${ }^{1}$ China Institute of Geo-Environmental Monitoring, Beijing, China \\ ${ }^{2}$ Shenyang Geological Survey Center, CGS, Shenyang, China
}

\begin{abstract}
Water resources play an important role in the natural environment, which is an irreplaceable resource for the survival and development of human society. Taking water resources as the research object, combined with the demand of social and economic development for water resources, this paper carried out the research on the evaluation method of cultivated land scale and urban construction scale under the constraints of water resources in Jinzhou. The results show that: the scale of cultivated land is 7215.98$7843.20 \mathrm{~km}^{2}$, which is in surplus. Heishan County has the largest scale of cultivated land and Guta District has the smallest scale of cultivated land. The urban construction land scale is $229.89-279.02 \mathrm{~km}^{2}$, which is in surplus. Taihe District and Yixian County are overloaded, and the rest are surplus. The evaluation results can support the determination and decomposition of planning objectives and indicators, and provide an important scientific basis for the implementation of local land spatial planning.
\end{abstract}

\section{Introduction}

Water resources play an important role in the natural environment, which is an irreplaceable resource for the survival and development of human society ${ }^{[1-3]}$. At present, due to the over exploitation and unreasonable utilization of water resources, the crisis of water resources shortage is increasing all over the world. Water resources and energy, population, ecological environment and other issues have become global issues of common concern around the world. The UN water conference once pointed out that "the water crisis will become another serious social crisis after the oil crisis". Taking water resources as the research object, combined with the demand of social and economic development for water resources, it is of great significance to carry out the research on the evaluation method of the carrying capacity of cultivated land scale and urban construction scale under the constraint of water resources, so as to grasp the basic situation of regional water resources carrying capacity, ensure the sustainable utilization of water resources and the sustainable development of social economy.

Many scholars have carried out a lot of research on water resources carrying capacity. Harris ${ }^{[4]}$ took the available amount of water resources as a factor affecting crop yield, focused on the agricultural carrying capacity of groundwater resources in agricultural production areas, determined the upper limit of agricultural productivity, and took this as a measure of regional development potential; Rijiberman ${ }^{[5]}$ took the carrying capacity as a measure of urban water resources security in the study of urban water resources evaluation and management
system.Naimi Ait-Aoudia ${ }^{[6]}$ evaluated the sustainable population of Algiers in terms of water resources and domestic consumption patterns; Custodio ${ }^{[7]}$ thinks that the critical discharge threshold of groundwater must be considered for ecosystem, and water quality and quantity are equally important for human and natural services, and introduces the experience of sustainable development of groundwater in Spain. Qu X. E. ${ }^{[8]}$ constructed a comprehensive evaluation index system of water resources carrying capacity covering water resources, society, economy and ecology, and used TOPSIS comprehensive evaluation method to calculate and study the dynamic changes and regional differences of water resources carrying capacity in Shaanxi Province.

In the past, the main body of water resources carrying capacity is not clear, and most of them are not quantified. The author thinks that water resources carrying capacity is based on a certain stage of development, economic and technological level, production and lifestyle, and the largest scale of human activities such as agricultural production and urban construction that can be supported by water resources in a certain region. This paper defines the main body of water resources and analyzes cultivated land scale and urban construction scale under the constraints of water resources in Jinzhou City, which can support the determination and decomposition of planning objectives and indicators, and provide an important scientific basis for the implementation of local land space planning.

a Corresponding author: lixiaolei@cigem.cn 


\section{The overview of the study area}

Jinzhou is located in the southwest of Liaoning Province, with Songling mountains in the north and Liaodong Bay in the Bohai Sea in the south. It is located in the east end of the "Liaoxi corridor", with sea, land and air transportation in all directions. It is a regional central city in western Liaoning Province and an important port city in the Bohai region. Jinzhou City has jurisdiction over Heishan, Beizhen, Linghai, Yixian, Linghe, Guta and Taihe districts, with a total area of $10048 \mathrm{~km}^{2}$.

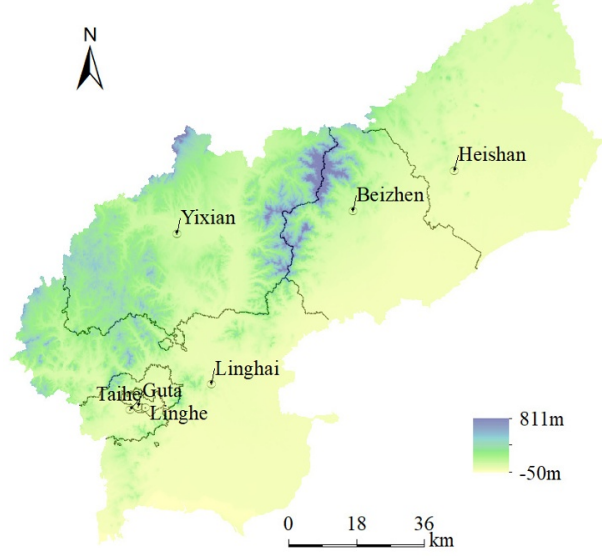

Fig.1. Topographic map of Jinzhou City.
Jinzhou is one of the cities with serious water shortage in northern China. The annual average total water resources is 1.4 billion $\mathrm{m}^{3}$, and the per capita water resources is only $455 \mathrm{~m}^{3}$, which is about $55 \%$ of the province's per capita water resources and $25 \%$ of the national per capita water resources. The annual average precipitation of Jinzhou is between $485-587 \mathrm{~mm}$, and the annual average total water resources of the whole city is 1.4 billion $\mathrm{m}^{3}$, and the available water is 1.28 billion $\mathrm{m}^{3}$.

\section{Data and method}

\subsection{Data}

The main data used in this study are as follows: total control amount of water consumption, current water use structure, agricultural planting structure, net irrigation quota of main crops, effective utilization coefficient of irrigation water, current dry land area, urban per capita construction land area and current urban resident population, which are shown in Table1.

Table 1. List of main data and source.

\begin{tabular}{|c|c|c|c|}
\hline $\begin{array}{c}\text { Serial } \\
\text { number }\end{array}$ & Data & Time & Data Source \\
\hline 1 & $\begin{array}{l}\text { Total control amount of water } \\
\text { consumption }\end{array}$ & 2017 & General Office of Jinzhou Municipal People's Government \\
\hline 2 & Current water use structure & 2018 & Water resources bulletin \\
\hline 3 & Agricultural planting structure & 2017 & Statistical yearbook \\
\hline 4 & Net irrigation quota of main crops & - & $\begin{array}{l}\text { Local standard of Liaoning Province -Industry water-use quota } \\
\text { (DB21/T 1237-2015) }\end{array}$ \\
\hline 5 & $\begin{array}{l}\text { Effective utilization coefficient of } \\
\text { irrigation water }\end{array}$ & $\longrightarrow$ & General Office of Jinzhou Municipal People's Government \\
\hline 6 & Current dry land area & 2020 & The third national land survey \\
\hline 7 & Urban living water quota & & $\begin{array}{l}\text { The standard of water quantity for city's residential use } \\
\text { (GB/T 50331-2002) }\end{array}$ \\
\hline 8 & $\begin{array}{c}\text { Urban per capita construction land } \\
\text { area }\end{array}$ & & $\begin{array}{l}\text { Code for classification of urban land use and planning standards of } \\
\text { development land (GB50137-2011) }\end{array}$ \\
\hline 9 & Current urban resident population & 2019 & General Office of Jinzhou Municipal People's Government \\
\hline
\end{tabular}

\subsection{Method}

\subsubsection{Cultivated land scale}

From the perspective of water resources, the cultivated land scale includes irrigation area and cultivated land with natural precipitation as the water source (rain fed cultivated land area). In this evaluation, the area of rain fed farmland is expressed as dry land area.

The carrying irrigation area of cultivated land is equal to the ratio of available irrigation water and comprehensive irrigation quota under certain conditions. Among them, the available irrigation water is determined on the basis of total control amount of water consumption, combined with regional water supply, consumption structure, grain production task, structure of primary, secondary and tertiary industries and other scenarios. In the actual evaluation, combined with the relevant results of water resources allocation, total control amount of water consumption is multiplied by the proportion of irrigation water to get the available irrigation water. According to the actual situation of local agricultural production and based on the irrigation quota of regional representative crops (such as corn, rice, wheat, etc.), the comprehensive irrigation quota of farmland is determined under different planting structure, multiple cropping situation, irrigation method (flood irrigation, pipe irrigation, drip irrigation, sprinkler irrigation, etc.) and effective utilization coefficient of irrigation water. The specific calculation formula is as follows:

$$
S_{t}=S_{i}+S_{r}
$$




$$
\begin{aligned}
S_{i} & =\frac{W_{i}}{F \times D} \\
W_{i} & =W_{0} \times K_{i} \\
F & =\frac{S_{s}}{S_{c}} \\
D & =\frac{1}{\eta} \sum_{i=1}^{n} B_{i} \times D_{n i}
\end{aligned}
$$

$S_{t}$ is cultivated land scale, $S_{i}$ is irrigation land scale, $S_{r}$ is nonirrigated farmland scale, $W_{i}$ is available water for irrigation, $\mathrm{F}$ is multiple crop index, $D$ is comprehensive irrigation quota, $W_{0}$ is total control amount of water consumption, $K_{i}$ is proportion of irrigation water, $S_{s}$ is gross sown area, $S_{c}$ is cultivated land area, $\eta$ is effective utilization coefficient of irrigation water, $B_{i}$ is area proportion of crop $i, D_{n i}$ is irrigation quota of crop $i, n$ is the number of crops.

\subsubsection{Urban construction scale}

From the perspective of water resources, the urban population scale is determined by dividing the regional urban available water by the urban per capita water demand, and the bearable construction land scale is obtained by multiplying the bearable urban population scale by the per capita urban construction land area. Urban available water should be determined on the basis of total control amount of water consumption, combined with regional water supply and consumption structure, process technology, industrial production task, structure of primary, secondary and tertiary industries and other scenarios. Urban per capita water demand needs to consider different development stages, economic and technological levels, production and lifestyle scenarios, determine the reasonable proportion of urban residents' per capita living and industrial water consumption respectively, and comprehensively determine according to the sub weight of the two. The specific calculation formula is as follows:

$$
\begin{aligned}
& U=R \times A \\
& R=\frac{W_{c}}{M_{c}}
\end{aligned}
$$

$$
\begin{aligned}
& W_{c}=W_{l i}+W_{i n} \\
& M_{c}=M_{l i}+M_{i n} \\
& W_{l i}=W_{0} \times K_{l i} \\
& W_{i n}=W_{0} \times K_{i n}
\end{aligned}
$$

$U$ is urban construction scale, $R$ is urban population scale, $A$ is per capita construction land area, $W_{c}$ is urban available water, $W_{l i}$ is urban living available water, $W_{i n}$ is urban industry available water, $M_{c}$ is urban per capita water demand, $M_{l i}$ is per capita water demand of urbanliving, $M_{\text {in }}$ is per capita water demand of urban industry, $W_{0}$ is total control amount of water consumption, $K_{l i}$ is proportion of living water, $K_{i n}$ is proportion of industrial water.

\section{Results}

(1) The total current cultivated land in Jinzhou City is $5212.89 \mathrm{~km}^{2}$, including $220.20 \mathrm{~km}^{2}$ of irrigated land and $4992.69 \mathrm{~km}^{2}$ of dry land. The results show that the carrying capacity of cultivated land scale of 7 districts and counties in Jinzhou City is $7215.98-7843.20 \mathrm{~km}^{2}$, which is in surplus. Among them, Heishan County has the largest scale and Guta District has the smallest scale(Table 2).

(2) The current urban construction land of Jinzhou City is $204.91 \mathrm{~km}^{2}$. The evaluation results show that the carrying capacity of urban construction land in Jinzhou City is $229.89-279.02 \mathrm{~km}^{2}$ under the constraints of water resources, which is in a surplus state on the whole. Taihe District and Yixian County are overloaded, and the rest are surplus(Table 3). To solve the problem of overloading in Taihe District and Yixian County, we can start from the

\begin{tabular}{|c|c|c|c|c|c|c|}
\hline $\begin{array}{c}\text { Serial } \\
\text { number }\end{array}$ & $\begin{array}{c}\text { Administrative } \\
\text { Region }\end{array}$ & $\begin{array}{c}\text { Current cultivated } \\
\text { land area }\end{array}$ & $\begin{array}{c}\text { Carrying } \\
\text { capacity scale }^{\mathrm{a}}\end{array}$ & $\begin{array}{c}\text { Carrying } \\
\text { capacity state }^{\mathrm{a}}\end{array}$ & $\begin{array}{c}\text { Carrying } \\
\text { capacity scale }^{\mathrm{b}}\end{array}$ & $\begin{array}{c}\text { Carrying } \\
\text { capacity state }^{\mathrm{b}}\end{array}$ \\
\hline 1 & Guta & 0.97 & 1.16 & Surplus & 1.10 & Surplus \\
\hline 2 & Linghe & 1.76 & 1.96 & Surplus & 1.85 & Surplus \\
\hline 3 & Taihe & 114.71 & 161.29 & Surplus & 153.94 & Surplus \\
\hline 4 & Heishan & 1895.38 & 2876.87 & Surplus & 2758.95 & Surplus \\
\hline 5 & Yixian & 1106.61 & 1622.66 & Surplus & 1462.52 & Surplus \\
\hline 6 & Linghai & 1296.95 & 1771.72 & Surplus & 1721.00 & Surplus \\
\hline 7 & Beizhen & 796.51 & 1407.54 & Surplus & 1116.62 & Surplus \\
\hline 8 & Total & 5212.89 & 7843.20 & Surplus & 7215.98 & Surplus \\
\hline
\end{tabular}
following two aspects: one is to improve the total amount of water control; the other is to save water. The construction land that Taihe District and Yixian County can carry can reach a balanced state if the total water consumption of Taihe District increased by $30 \%$ or the per capita urban water demand decreased by $30 \%$, or the total water consumption of Yixian County increased by $9 \%$ or the per capita urban water demand decreased by $9 \%$.

Table 2. Cultivated land scale under the restriction of water resources.

Note: the scale of cultivated land is related to irrigation water quota and is affected by precipitation probability.

Carrying capacity scale ${ }^{a}$ : low irrigation quota (precipitation probability $P=50 \%$ )

Carrying capacity scale ${ }^{b}$ : high value of irrigation quota (precipitation probability $P=50 \%$ ) 
Table 3. Urban construction land scale under the restriction of water resources.

\begin{tabular}{|c|c|c|c|c|c|c|}
\hline $\begin{array}{c}\text { Serial } \\
\text { number }\end{array}$ & $\begin{array}{c}\text { Administrative } \\
\text { Region }\end{array}$ & $\begin{array}{c}\text { Current construction } \\
\text { land area }\end{array}$ & $\begin{array}{c}\text { Carrying } \\
\text { capacity scale }^{\mathbf{a}}\end{array}$ & $\begin{array}{c}\text { Carrying } \\
\text { capacity sate }^{\mathbf{a}}\end{array}$ & $\begin{array}{c}\text { Carrying }_{\text {capacity scale }^{\mathbf{b}}} \\
\text { capacity sate }^{\mathbf{b}}\end{array}$ \\
\hline 1 & Guta & 12.10 & 15.63 & Surplus & 12.87 & Surplus \\
\hline 2 & Linghe & 12.32 & 17.86 & Surplus & 14.71 & Surplus \\
\hline 3 & Taihe & 37.82 & 25.11 & Overload & 20.69 & Overload \\
\hline 4 & Heishan & 33.91 & 50.22 & Surplus & 41.38 & Surplus \\
\hline 5 & Yixian & 21.46 & 19.53 & Overload & 16.09 & Overload \\
\hline 6 & Linghai & 65.06 & 94.87 & Surplus & 78.17 & Surplus \\
\hline 7 & Beizhen & 22.25 & 55.81 & Surplus & 45.98 & Surplus \\
\hline $\mathbf{8}$ & Total & $\mathbf{2 0 4 . 9 1}$ & $\mathbf{2 7 9 . 0 3}$ & Surplus & $\mathbf{2 2 9 . 9 0}$ & Surplus \\
\hline
\end{tabular}

Note: the scale of urban construction land is related to the population scale, and the population scale is related to the per capita domestic water quota.

Carrying capacity scale ${ }^{a}$ : high population scale (low value of per capita living water quota) $\times$ per capita construction land standard Carrying capacity scale : low population scale (high value of per capita living water quota) $\times$ per capita construction land standard

\section{Conclusions}

The cultivated land scale under the restriction of water resources is $7215.98-7843.20 \mathrm{~km}^{2}$, which is in surplus. Heishan County is the largest and Guta District is the smallest.

The urban construction land scale under the restriction of water resources is $229.89-279.02 \mathrm{~km}^{2}$, which is in surplus. Taihe District and Yixian County are overloaded, and the rest are surplus.

\section{Acknowledgments}

This study was supported by China Geological Survey (No. DD20190506).

\section{References}

1. Brown A, Matlock M.D. (2011)A review of water scarcity indices and methodologies[R]. The Sustainability Consortium. White Paper\# 106.

2. Bernhardt Emily Bernhardt, Stuart E, Bunn, David D. Hart, et al. (2006)Perspective: The challenge of ecologically sustainable water management $[\mathrm{J}]$. Water Policy. 8 (5):475-479.

3. Li R.M.,Yin Z.Q.,Wang Y.,et al.(2018)Geological resources and environmental carrying capacity evaluation review, theory, and practice in China[J]. China Geology, 1,556-565.

4. Harris Jonathan M. (1999) Carrying capacity in Agriculture[J]. Globe and regional issue . Ecological Economics.129(3):443-461 .

5. Rijiberman.J, et al.(2000)Different approaches to assessment of design and management of sustainable urban water system[J]. Environment Impact Assessment Review.129(3):333-345.

6. Naimi Ait-Aoudia, M., \& Berezowska-Azzag, E. (2016) Water resources carrying capacity assessment: The case of Algeria's capital city. Habitat International, 58, 51-58.

7. Custodio Emilio, Sahuquillo Andrs, Albiac Jos. (2019) Sustainability of intensive groundwater development: experience in Spain[J]. Sustainable Water Resources Management, 5:11-26.

8. Qu X.E.(2017) Comprehensive evaluation of water resources carrying capacity in Shaanxi province [J]. Journal of Arid Land Resources and Environment, 31(02):91-97. 